\title{
Plasma Total Homocysteine and its Relationship with Cardiovascular Disease
}

\author{
D. Obersby, D.C. Chappell and A.A. Tsiami*
}

University of West London, School of Psychology, Social Work and Human Sciences, Paragon House, Boston Manor Road, Brentford, Middlesex, TW8 9GA, UK

\begin{abstract}
Aims: The specific aim of this review was to compile the first systematic review of systematic reviews and meta-analyses from a range of studies that evaluates the evidence that elevated homocysteine may be a risk factor for CVD.

Data Synthesis: 379 entries were identified by initial screening using set criteria revealing eleven meta-analyses, one systematic review, two systematic reviews/meta-analyses and ten other studies, between 1994 and 2013. These studies compared homocysteine levels and its relationship with twelve different types of CVD chronic conditions. Final methodological quality assessment was conducted independently using the instrument AMSTAR for the systematic reviews and meta-analyses. The remaining studies were assessed using data extraction tools from JBI QARI, Appendix 2 \& 4 packages.

Conclusions: From the selected studies, $82.8 \%$ of the CVD conditions demonstrated that epidemiologic and clinical data strongly indicated that elevated homocysteine levels is a risk factor for primary CVD. $71.4 \%$ of the CVD conditions demonstrated that plasma tHcy can be employed as an independent biomarker. Despite $46.2 \%$ of the CVD conditions finding that reducing plasma tHcy lowers the risk of many CVD events, it remains unclear whether the reduction in plasma tHcy will reduce the risk of some CVD events; it is therefore considered prudent to take precautionary measures to aim for normal levels of homocysteine to avoid the risk of developing or exacerbating CVD. Moreover, it was shown that levels of homocysteine can be profoundly affected by diet, supplementation and lifestyle.
\end{abstract}

The present study will help to clarify the present scientific understanding of this subject.

Keywords: Hyperhomocysteinemia, cardiovascular disease, metabolism, diet, lifestyle.

\section{INTRODUCTION}

Many published studies have addressed the question, 'is elevated plasma tHcy related to CVD'? The present study reviews the research already undertaken and forms the first systematic review of systematic reviews and meta-analyses on this topic and aims to address the following questions:

1) Are elevated levels of plasma tHcy a risk factor for primary CVD?

2) Are elevated homocysteine levels a major independent biomarker for the risk of developing CVD?

3) Does normalising plasma tHcy reduce the risk of CVD?

Homocysteine is an intermediate product of the one-carbon metabolism. It is formed during the metabolism of methionine in the methionine cycle. Methionine from the diet is activated by adenosine triphosphate and used either for protein synthesis or the formation of SAM, which contains a very reactive

*Address correspondence to this author at the University of West London, School of Psychology, Social Work and Human Sciences, Paragon House, Boston Manor Road, Brentford, Middlesex, TW8 9GA, UK; Tel: +44 (0) 208209 4422; E-mail: amalia.tsiami@uwl.ac.uk methyl group. SAM is demethylated to $\mathrm{S}$ adenosylhomocysteine. In the transsulfuration pathway, homocysteine is converted to cystathionine by the enzyme cystathionine beta-synthase which requires the essential cofactor vitamin $B 6$. Homocysteine can also be remethylated through the folate cycle which is the major route for remethylation. In this route homocysteine is recycled to methionine in a reaction catalyzed by the enzyme methionine synthase which requires the essential vitamin B12, but only in its methylcobalamin form [1], see Figure 1.

Deficiencies in vitamin B6, B12, folate and betaine usually results in elevated plasma homocysteine.

The normal range of plasma tHcy level has been defined by Ravaglia et al. [2] as 5 to $15 \mu \mathrm{mol} / \mathrm{L}$, and $\mathrm{HHCY}$ at a plasma tHcy level of $>15 \mu \mathrm{mol} / \mathrm{L}$. Refsum et al. [3] defined $15 \mu \mathrm{mol} / \mathrm{L}$ to $30 \mu \mathrm{mol} / \mathrm{L}$ level of plasma tHcy as 'Moderate HHCY', $30 \mu \mathrm{mol} / \mathrm{L}$ to $100 \mu \mathrm{mol} / \mathrm{L}$ level of plasma tHcy as 'Intermediate HHCY' and > 100 $\mu \mathrm{mol} / \mathrm{L}$ level of plasma tHcy as 'Severe $\mathrm{HHCY}$ '.

\section{RESEARCH FINDINGS}

There is often a cluster of factors leading to elevated plasma tHcy levels. Many of these factors cause a change in plasma tHcy concentrations by 


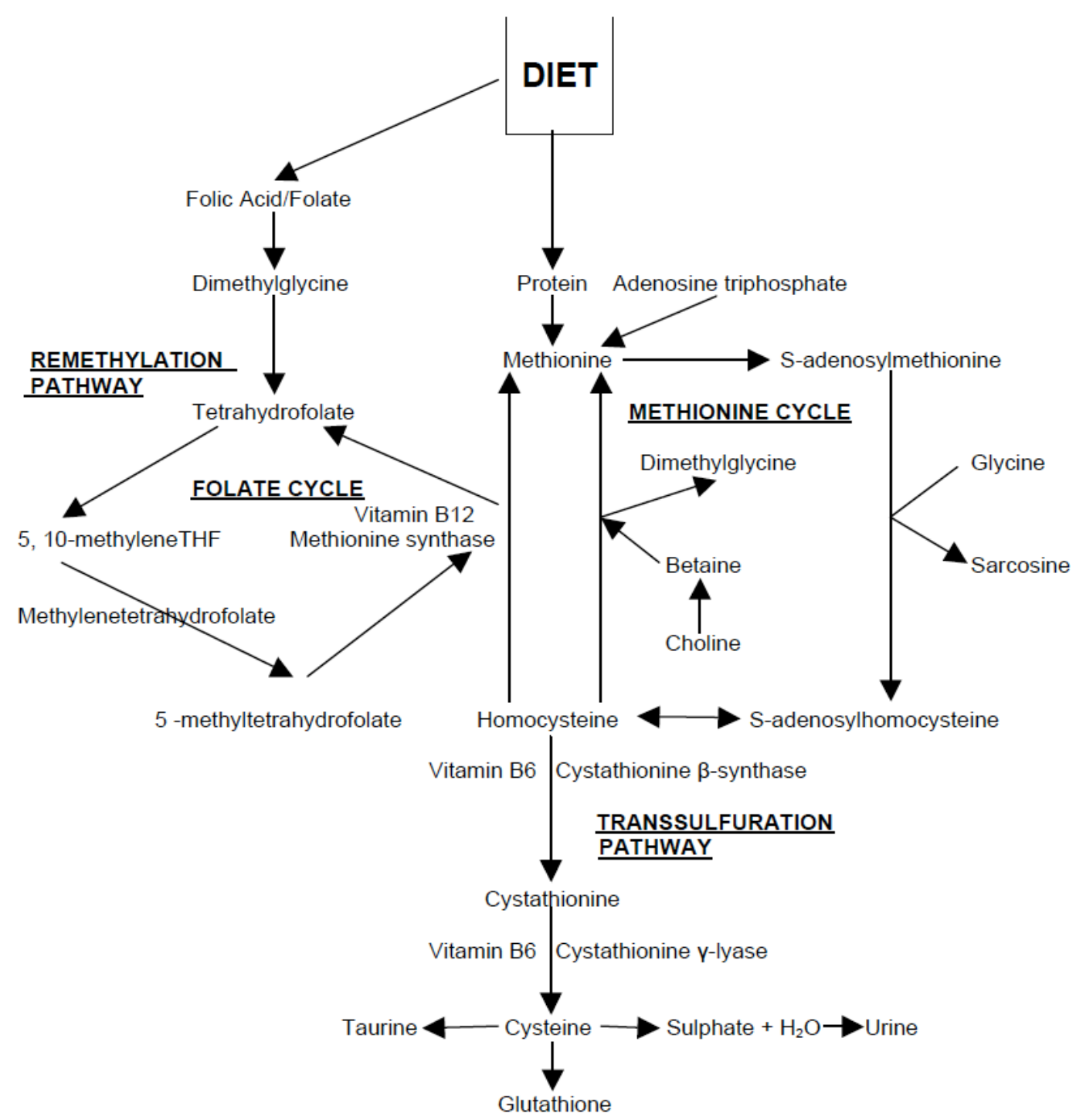

Figure 1: The methionine cycle, remethylation pathway of homocysteine to methionine via the folate cycle, the transsulfuration pathway, and the betaine reaction.

altering the function or plasma concentrations of the $\mathrm{B}$ vitamins, and/or by influencing renal function or more rarely by influencing enzyme activities [3].

\section{Homocystinuria and Defective MTHFR Enzyme}

Homocystinuria is a rare inborn autosomal recessive genetic disorder, characterised by massively increased levels of plasma tHcy, leading to severe HHCY [4]. According to Wilcken and Wilcken, [5] lowering elevated plasma tHcy in patients with homocystinuria (severe HHCY) due to CBS deficiency, greatly reduces cardiovascular risk. Much more common than homocystinuria are MTHFR mutations, such as MTHFR A1298C with the most common being the MTHFR C677T mutation. Related research has concluded that high tHcy concentration is typically associated with homozygosity for the $677 \mathrm{C} \rightarrow \mathrm{T}$ variant of MTHFR which occurs only with poor vitamin B2 status [6].

\section{Age and Gender}

According to Jacques et al. [7] levels of plasma tHcy rise with age, for males from a mean value of 6.84 $\mu \mathrm{mol} / \mathrm{L}$ at the age of 12 to 15 , rising to $12.4 \mu \mathrm{mol} / \mathrm{L}$ at the age of $80+$.

Over the same age range females plasma tHcy levels rise from a mean value of $6.12 \mu \mathrm{mol} / \mathrm{L}$ to 11.44 $\mu \mathrm{mol} / \mathrm{L}$.

\section{Raised Plasma Total Homocysteine Level During Female Menstruation}

During the menstrual cycle, mean homocysteine levels increase from an average of $7.8 \mu \mathrm{mol} / \mathrm{L}$ in the 
luteal phase to $8.9 \mu \mathrm{mol} / \mathrm{L}$ in the follicular phase, providing evidence that there are significant differences in plasma tHcy levels during the menstrual cycle [8].

\section{Raised Plasma tHcy Level of Vegetarians}

These individuals may be susceptible to elevated homocysteine, due to the lack of dietary animal produce and are potentially at risk to develop vitamin B12 deficiency homocysteine related chronic conditions [9]. Obersby et al. [9] recently demonstrated that a negative exponential relationship of the form $Y=A e^{-B X}$ exists between plasma tHcy and serum vitamin B12 for omnivores, LV-LOV's and vegans.

\section{Protein and B-Vitamins}

Excessive animal protein in the diet can raise homocysteine levels. Inadequate intake of B-vitamins results in reduced enzyme function with the potential to elevate plasma tHcy levels [10]. In the case of folate deficiency, plasma homocysteine may be increased 8 to 10 fold together with a 2.5 fold increase for vitamin B12 deficiency, but is less affected by vitamin B6 deficiency (except for heterozygous or homozygous of CBS deficiency) [11]. In 1996 the FDA issued a regulation requesting that all enriched grain products contain $140 \mu \mathrm{g}$ of folic acid per $100 \mathrm{~g}$. A subsequent study has confirmed that folic acid fortification has had a substantial effect on plasma folate and homocysteine concentrations [12]. In a population-based sample of middle-aged and older adults, plasma folate levels increased whilst homocysteine levels reduced by approximately $50 \%$ among those who did not take other supplements, resulting in a reduction of CVD in the USA by $2.9 \%$ per year and in Canada by $5.4 \%$ per year (1990 to 2002) [12].

\section{Salt}

Animal research has shown that a combination of high salt and high homocysteine levels cause the lining of the arteries to become more severely damaged, which is likely to increase susceptibility to heart disease [13].

\section{Saturated Fat}

It has been demonstrated [14] that high dietary levels of saturated fat raise homocysteine levels. Studies conducted on individuals consuming diets containing a range of saturated fat levels; show that low fat diets decreased homocysteine levels by $14 \%$, while high fat diets raised homocysteine levels by $10 \%$ [14].

\section{Betaine}

Dietary betaine is important because of its role in the donation of methyl groups to homocysteine to form methionine, hence helping to maintain homocysteine levels within normal limits. Betaine can be synthesized in the body from choline [15] (see Figure 1).

\section{Tea and Coffee}

A study carried out by Olthof [16] demonstrated that eight cups of coffee or black tea, (which contains high doses of chlorogenic acid and caffeine) per day, taken for a week raises homocysteine levels by $11 \%$ and $12 \%$ respectively.

\section{Alcohol}

Bleich et al. [17] demonstrated that plasma tHcy levels are raised by alcohol and the type of drink consumed. He gave $30 \mathrm{~g} /$ day of alcohol to three groups of social drinkers $(n=15)$ in the form of beer, red wine and spirits, mineral water was given to non-drinkers $(n=15)$ for six weeks. The mineral water group plasma thcy reduced from $9.06 \pm 2.08 \mu \mathrm{mol} / \mathrm{L}$ to $8.47 \pm 1.42$ $\mu \mathrm{mol} / \mathrm{L}$, while the beer group increased from $11.67 \pm$ 2.17 to $14.58 \pm 1.58 \mu \mathrm{mol} / \mathrm{L}$, red wine group increased from $12.69 \pm 1.85$ to $15.61 \pm 1.83 \mu \mathrm{mol} / \mathrm{L}$ and the spirit group increased from $13.8 \pm 2.22$ to $16.25 \pm 2.19$ $\mu \mathrm{mol} / \mathrm{L}$.

\section{Stress}

de Oliveira et al. [18] demonstrated with animal studies, which can be extrapolated to human pathology, that plasma tHcy concentrations were significantly altered by stress as compared to the control group by $+38 \%(P=0.006)$ [ i.e. mean $5.3 \mu \mathrm{mol} / \mathrm{L}$ to mean $7.31 \mu \mathrm{mol} / \mathrm{L}]$.

\section{Smoking}

Research shows that subjects who smoked $35.9 \pm$ 6.4 cigarettes daily and who ceased smoking, homocysteine levels decreased from $8.58 \pm 2.31$ to $7.53 \pm 2.26 \mu \mathrm{mol} / \mathrm{L}(P=0.013)$. Significant changes in homocysteine levels were not observed in subjects who reduced smoking or continued to smoke [19].

\section{HHCY and CVD}

In essence, CVD refers to those diseases related to atheroma, arteriosclerosis and atherosclerosis. All three terms refer to pathophysiological changes in the 
blood vessels. McCully was first to propose that $\mathrm{HHCY}$ may be a vascular factor. McCully's hypothesis was confirmed by subsequent studies by Refsum et al. [20] and Welch \& Loscalzo [21]. linking HHCY to PAD, stroke, and coronary artery disease.

There is now an apparent abundance of evidence which demonstrates that there is a link between CVD and elevated homocysteine. However, Khandanpour et al. [22] only found weak evidence on the clinical beneficial effects of folate supplementation in PAD. Furthermore, Ford et al. [23] supports a role for homocysteine in the pathogenesis of CHD, but concluded that more epidemiological studies are needed.

Humphrey et al. [24] and Ueland et al. [25] have demonstrated that each increase of $5 \mu \mathrm{mol} / \mathrm{L}$ in homocysteine increases the risk of $\mathrm{CHD}$ by approximately $20 \%$, independently of traditional CHD risk factors. It is well documented [26-28] that the risk for CHD is represented by a continuum of homocysteine concentrations with a substantial risk occurring at $\geq 10 \mu \mathrm{mol} / \mathrm{L}$ [26-28]. Robinson et al. [29] reports that any homocysteine level over $6.3 \mu \mathrm{mol} / \mathrm{L}$ represents an increase risk of $\mathrm{CHD}$.

\section{Impaired Renal Function}

Studies indicate that the kidneys account for approximately $70 \%$ of plasma clearance of homocysteine [30]. A common cause of hyperhomocysteinemia is a decline in renal function [31]. Studies have reported a strong inverse relationship between glomerular filtration rate and plasma tHcy levels [31].

\section{Evidence Supporting the Pathology of Heightened Homocysteine and CVD}

Excess homocysteine promotes CVD due to the following possible mechanisms:

Homocysteine has a reactive product, HCYT. This compound converts LDL to form small dense particles associated with increased susceptibility to vascular disease. HCYT also causes platelets to aggregate. Furthermore, HCYT becomes linked to the apoB protein of LDL by peptide-bound homocysteinyl groups, causing aggregation and precipitation of the LDL particles. The homocysteine-LDL aggregates are taken up by macrophages to form foam cells. In the artery wall, foam cells lead to deposition of cholesterol and fats creating arteriosclerotic plaques within the arterial walls [20, 32-37].
HCYT contributes to changes in coagulation factor levels so as to encourage blood clot formation [20, 3237].

HCYT is believed to prevent small arteries from dilating so they are more vulnerable to obstruction [20, 32-37].

HCYT causes smooth muscle cells in the arterial wall to proliferate [20,32-37].

HCYT generates superoxide and hydrogen peroxide, which have been linked to damage to arterial endothelium and enhances thrombogenicity [21, 38].

It has been shown that raised homocysteine depletes magnesium, causing calcium to flood into smooth muscle cells of vascular vessels that result in vasospasms that raise blood pressure and can lead to angina and heart attack [38-41].

In general, epidemiologic studies show an independent and graded association between homocysteine levels and cardiovascular risk [42-44]. Moreover, Boushey et al. [43] has demonstrated that a $5 \mu \mathrm{mol} / \mathrm{L}$ increase in plasma $\mathrm{tHcy}$ is associated with an increased risk of CVD by an odds ratio of 1.60 in men and 1.80 for women.

\section{Further Considerations}

Brattstrom and Wilcken [45] concluded that much of the epidemiologic association found in prospective and retrospective studies as well as cross-sectional studies between modestly elevated plasma tHcy and cardiovascular risk or severity of atherosclerosis is often explained by renal mechanism malfunction. This constitutes the basis of their hypothesis, which implies that moderate $\mathrm{HHCY}$ in association with atherosclerotic CVD is a consequence but not a cause of the disease. There is however, considerable epidemiologic evidence that moderate $\mathrm{HHCY}$ is a risk factor for venous thromboembolic disease, as reviewed by a metaanalysis conducted by Ray [46] supported by Eichinger et al. [47] and Langman et al. [48]. Moreover, a correlation between $\mathrm{HHCY}$ and arterial vascular disease is well established $[49,50]$.

\section{MATERIALS AND METHODS}

\section{Evidence in Research Publications}

A computer assisted literature search was made for relevant studies using the search term 
Table 1: Details of Selected Systematic Reviews, Meta-Analyses and other Studies on Hyperhomocysteinemia and Cardiovascular Disease Covering Twelve Different Types of chronic Conditions

\begin{tabular}{|c|c|c|c|c|}
\hline $\begin{array}{l}\text { Title of review } \\
\text { Author's name } \\
\text { Reference }\end{array}$ & $\begin{array}{l}\text { Number of } \\
\text { Eligible } \\
\text { Studies }\end{array}$ & $\begin{array}{l}\text { Number of } \\
\text { Participants } \\
\text { involved }\end{array}$ & Conclusions & Type \\
\hline $\begin{array}{l}\text { Hyperhomocysteinemia and } \\
\text { low pyridoxal phosphate } \\
\text { common and independent } \\
\text { reversible risk factors for CVD. } \\
\text { Robinson et al. [29]. }\end{array}$ & 1 & 535 & $\begin{array}{c}\text { The risk of CHD rises with increasing plasma } \\
\text { homocysteine regardless of age and sex, with no } \\
\text { threshold effect. }\end{array}$ & $\begin{array}{l}\text { Cohort case } \\
\text { study }\end{array}$ \\
\hline $\begin{array}{l}\text { Homocysteine metabolism } \\
\text { and risk of myocardial } \\
\text { infarction: relation with vitamin } \\
\text { B6, B12 and folate. myocardial } \\
\text { Verhoef et al. [59]. }\end{array}$ & 1 & 248 & $\begin{array}{l}\text { Adds further epidemiologic evidence to the } \\
\text { hypothesis that plasma homocysteine is an } \\
\text { important independent risk factor for coronary } \\
\text { disease. There is strong direct linear trend of } \\
\text { plasma thcy with the risk of infarction. }\end{array}$ & $\begin{array}{l}\text { Case } \\
\text { control } \\
\text { study }\end{array}$ \\
\hline $\begin{array}{l}\text { Meta-analysis of } \\
\text { hyperhomocysteinemia as a } \\
\text { risk factor for venous } \\
\text { thromboembolic disease. } \\
\text { Ray [46]. }\end{array}$ & 9 & 487 & $\begin{array}{l}\text { A significant risk for venous thromboembolic } \\
\text { disease in the presence of hyperhomocysteinemia } \\
\text { apparently exists among a spectrum of patients with } \\
\text { first or recurrent venous thromboembolic events. } \\
\text { The risk appears to be most significant for patients } \\
<60 \text { years old. }\end{array}$ & $\begin{array}{l}\text { Meta- } \\
\text { analysis }\end{array}$ \\
\hline $\begin{array}{l}\text { The controversy over } \\
\text { homocysteine and } \\
\text { cardiovascular risk. } \\
\text { Ueland et al. [25]. }\end{array}$ & 14 & 13980 & $\begin{array}{c}\text { Hyperhomocysteinemia and preclinical } \\
\text { atherosclerosis suggest that elevated plasma total } \\
\text { homocysteine is a causal risk factor for } \\
\text { cardiovascular disease including venous } \\
\text { thrombosis. }\end{array}$ & $\begin{array}{c}\text { Meta- } \\
\text { analysis }\end{array}$ \\
\hline $\begin{array}{l}\text { Hyperhomocysteinemia and } \\
\text { increased risk of venous } \\
\text { thromboembolism. } \\
\text { Langman et al. [48]. }\end{array}$ & 1 & 280 & $\begin{array}{c}\text { Hyperhomocysteinemia is a significant risk factor } \\
\text { for venous thromboembolic disease. It is likely that } \\
\text { hyperhomocysteinemia plays a causative role in the } \\
\text { development of venous thrombosis. }\end{array}$ & $\begin{array}{l}\text { Case- } \\
\text { control } \\
\text { study }\end{array}$ \\
\hline $\begin{array}{l}\text { Total plasma homocysteine } \\
\text { level and risk of } \\
\text { cardiovascular disease A } \\
\text { meta-analysis of prospective } \\
\text { cohort studies. } \\
\text { Bautista et al. [52]. }\end{array}$ & 14 & 9834 & $\begin{array}{c}\text { Hyperhomocysteinemia moderately increases the } \\
\text { risk of a first cardiovascular event, regardless of } \\
\text { age and follow-up duration. }\end{array}$ & $\begin{array}{l}\text { Meta- } \\
\text { analysis }\end{array}$ \\
\hline
\end{tabular}


(Table 1). Continued.

\begin{tabular}{|c|c|c|c|c|}
\hline $\begin{array}{l}\text { Title of review } \\
\text { Author's name } \\
\text { Reference }\end{array}$ & $\begin{array}{l}\text { Number of } \\
\text { Eligible } \\
\text { Studies }\end{array}$ & $\begin{array}{l}\text { Number of } \\
\text { Participants } \\
\text { involved }\end{array}$ & Conclusions & Type \\
\hline $\begin{array}{l}\text { Homocysteine and } \\
\text { cardiovascular disease: a } \\
\text { systematic review of the } \\
\text { evidence on case-control } \\
\text { studies and nested case- } \\
\text { control studies. } \\
\text { Ford et al [23]. }\end{array}$ & 57 & 12855 & $\begin{array}{l}\text { Homocysteine concentration is only weakly related } \\
\text { to coronary heart disease and somewhat more } \\
\text { strongly related to cerebrovascular disease. } \\
\text { Although other lines of evidence support a role for } \\
\text { homocysteine in the pathogenesis of cardiovascular } \\
\text { disease, more information from prospective } \\
\text { epidemiological studies or clinical trials is needed to } \\
\text { clarify this role. }\end{array}$ & $\begin{array}{c}\text { Systematic } \\
\text { review }\end{array}$ \\
\hline $\begin{array}{l}\text { Homocysteine and risk of } \\
\text { ischaemic heart disease and } \\
\text { stroke: a meta-analysis The } \\
\text { Homocysteine Studies } \\
\text { Collaboration. [54]. }\end{array}$ & 30 & 6186 & $\begin{array}{l}\text { Lowering plasma homocysteine by } 3 \mu \mathrm{mol} / \mathrm{L} \text { was } \\
\text { accompanied by a lower risk of ischaemic heart } \\
\text { disease by } 11 \% \text { and by a lower risk of stroke by } \\
19 \% \text { The meta-analysis suggests that elevated. } \\
\text { homocysteine is at most a modest independent } \\
\text { predictor of ischaemic heart disease and risk of } \\
\text { stroke in a healthy population. }\end{array}$ & $\begin{array}{l}\text { Meta- } \\
\text { analysis }\end{array}$ \\
\hline $\begin{array}{l}\text { Homocysteine and } \\
\text { cardiovascular disease: } \\
\text { evidence on causality from by } \\
\text { a meta-analysis } \\
\text { Wald et al. [42]. }\end{array}$ & 92 & 20669 & $\begin{array}{l}\text { Lowering homocysteine concentrations by } 3 \mu \mathrm{mol} / \mathrm{L} \\
\text { would reduce the risk of ischaemic heart disease by } \\
16 \% \text {, deep vein thrombosis } 25 \% \text { and stroke by } \\
24 \% \text {. }\end{array}$ & $\begin{array}{l}\text { Meta- } \\
\text { analysis }\end{array}$ \\
\hline $\begin{array}{l}\text { Prospective study of serum } \\
\text { homocysteine and risk of } \\
\text { ischemic stroke among } \\
\text { patients with pre-existing } \\
\text { coronary heart disease. } \\
\text { Tanne et al. [53]. }\end{array}$ & Not stated & 160 & $\begin{array}{c}\text { Serum total homocysteine concentration is a strong } \\
\text { predictor for incident ischemic stroke among } \\
\text { patients at increased risk because of chronic } \\
\text { coronary heart disease. The graded association } \\
\text { observed is independent of traditional risk factors or } \\
\text { markers inflammatory and indicates the importance } \\
\text { of serum homocysteine levels in patients with pre- } \\
\text { existing vascular disease. }\end{array}$ & $\begin{array}{l}\text { Case } \\
\text { control } \\
\text { study }\end{array}$ \\
\hline $\begin{array}{l}\text { Hyperhomocysteinemia as a } \\
\text { risk factor for coronary } \\
\text { atherosclerotic disease in the } \\
\text { elderly. } \\
\text { Gravina-Taddei et al. [68]. }\end{array}$ & 1 & 172 & $\begin{array}{c}\text { Hyperhomocysteinemia was an independent risk } \\
\text { factor for coronary artery disease in elderly } \\
\text { individuals. }\end{array}$ & $\begin{array}{l}\text { Case } \\
\text { control } \\
\text { study }\end{array}$ \\
\hline $\begin{array}{l}\text { Homocysteine lowering with B } \\
\text { vitamins in vascular disease. } \\
\text { The Heart Outcome } \\
\text { Prevention Evaluation } \\
\text { (HOPE2) Investigation, [62]. }\end{array}$ & 1 & 5522 & $\begin{array}{l}\text { Supplements combining vitamin B12 and folic acid } \\
\text { did reduce homocysteine, but apparently did not } \\
\text { reduce the risk of major cardiovascular events in } \\
\text { patients with vascular disease. }\end{array}$ & $\begin{array}{c}\text { Cohort } \\
\text { case study }\end{array}$ \\
\hline $\begin{array}{l}\text { Folic acid improves vascular } \\
\text { reactivity in humans: a meta- } \\
\text { meta- analysis of RCT's. } \\
\text { de Bree et al. [60]. }\end{array}$ & 14 & 732 & $\begin{array}{c}\text { Folic acid administration beneficially affects } \\
\text { endothelial function by lowering homocysteine } \\
\text { concentration, which potentially reduces risk of } \\
\text { cardiovascular. disease. }\end{array}$ & $\begin{array}{l}\text { Meta- } \\
\text { analysis }\end{array}$ \\
\hline $\begin{array}{l}\text { Efficacy of folic acid } \\
\text { supplementation in stroke } \\
\text { prevention: A meta-analysis. } \\
\text { Wang et al. [58]. }\end{array}$ & 8 & 16841 & $\begin{array}{l}\text { The meta-analysis provides coherent evidence that } \\
\text { folic acid supplementation can significantly reduce } \\
\text { risk of stroke in primary prevention by its effect on } \\
\text { plasma homocysteine concentrations. }\end{array}$ & $\begin{array}{l}\text { Meta- } \\
\text { analysis }\end{array}$ \\
\hline $\begin{array}{l}\text { Risk prediction, homocysteine } \\
\text { in coronary heart disease. } \\
\text { Govindaraju \& Manjunath [57]. }\end{array}$ & 1 & 273 & $\begin{array}{c}\text { Elevated homocysteine is related to } C A D \text { and is the } \\
\text { best predictor with an odds ratio of } 83.2 \text { amongst } \\
\text { other conventional risk factor in CAD patients. }\end{array}$ & $\begin{array}{l}\text { Case } \\
\text { control } \\
\text { study }\end{array}$ \\
\hline $\begin{array}{l}\text { Homocysteine level and } \\
\text { coronary heart disease } \\
\text { incidence: a systematic review } \\
\text { and meta-analysis } \\
\text { Humphrey et al. [24]. }\end{array}$ & 26 & Not stated & $\begin{array}{c}\text { Each increase of } 5 \mu \mathrm{mol} / \mathrm{L} \text { in homocysteine level } \\
\text { increases the risk of coronary heart disease events } \\
\text { by } 20 \% \text {, independently of traditional coronary heart } \\
\text { disease risk factors. }\end{array}$ & $\begin{array}{l}\text { Systematic } \\
\text { review and } \\
\text { meta- } \\
\text { analysis }\end{array}$ \\
\hline
\end{tabular}


(Table 1). Continued.

\begin{tabular}{|c|c|c|c|c|}
\hline $\begin{array}{l}\text { Title of review } \\
\text { Author's name } \\
\text { Reference }\end{array}$ & $\begin{array}{l}\text { Number of } \\
\text { Eligible } \\
\text { Studies }\end{array}$ & $\begin{array}{l}\text { Number of } \\
\text { Participants } \\
\text { involved }\end{array}$ & Conclusions & Type \\
\hline $\begin{array}{l}\text { Homocysteine and peripheral } \\
\text { arterial stated disease: } \\
\text { systematic review and meta- } \\
\quad \text { analysis } \\
\text { Khandanpour et al. [22]. }\end{array}$ & 33 & Not & $\begin{array}{c}\text { Patients with peripheral arterial disease have } \\
\text { significantly higher homocysteine levels than } \\
\text { unaffected controls. However, no robust evidence } \\
\text { on clinically beneficial effects of folate } \\
\text { supplementation in peripheral arterial disease was } \\
\text { found. }\end{array}$ & $\begin{array}{l}\text { Systematic } \\
\text { review and } \\
\text { meta- } \\
\text { analysis }\end{array}$ \\
\hline $\begin{array}{l}\text { Effects of lowering } \\
\text { homocysteine levels with B } \\
\text { vitamins on cardiovascular } \\
\text { disease, cancer, and cause- } \\
\text { specific mortality. } \\
\text { Clarke et al [63]. }\end{array}$ & 8 & 37485 & $\begin{array}{c}\text { Lowering homocysteine levels by } 25 \% \text { has no } \\
\text { significant effect on the incident of major vascular } \\
\text { events, over a five year period. }\end{array}$ & $\begin{array}{c}\text { Meta- } \\
\text { analysis }\end{array}$ \\
\hline $\begin{array}{l}\text { Homocysteine and } \\
\text { reclassification of } \\
\text { cardiovascular disease risk. } \\
\text { Veeranna et al. [55]. }\end{array}$ & 2 & 13247 & $\begin{array}{l}\text { From these two disparate population cohorts, it was } \\
\text { found that the addition of Hcy level to Framingham } \\
\text { Risk Score significantly improved risk prediction, } \\
\text { especially in individuals at intermediate risk of CHD. } \\
\text { events. }\end{array}$ & $\begin{array}{c}\text { Meta- } \\
\text { analysis }\end{array}$ \\
\hline $\begin{array}{l}\text { Homocysteine and coronary } \\
\text { heart disease: meta-analysis } \\
\text { of MTHFR case-control } \\
\text { studies, avoiding publication } \\
\text { bias } \\
\text { Clarke et al. [67]. }\end{array}$ & 19 & 116136 & $\begin{array}{c}\text { The overall result from large unpublished datasets } \\
\text { shows lifelong moderate homocysteine elevation } \\
\text { has little or no effect on CHD. The discrepant } \\
\text { overall result from previously published studies } \\
\text { reflects publication bias or methodological } \\
\text { problems. }\end{array}$ & $\begin{array}{c}\text { Meta- } \\
\text { analysis }\end{array}$ \\
\hline $\begin{array}{l}\text { C1 metabolism and } \\
\text { cardiovascular disease in } \\
\text { older adults } \\
\text { McNulty et al. [61]. }\end{array}$ & 6 & 29653 & $\begin{array}{l}\text { Most of the RCTs designed to show a causative } \\
\text { relationship between outcomes total homocysteine } \\
\text { and cardiovascular disease provide little evidence } \\
\text { that giving B-vitamins to cardiovascular disease } \\
\text { patients prevent another event. The same cannot } \\
\text { be said for prevention. Emerging nutrition policy } \\
\text { should consider nutrient requirements aimed at } \\
\text { primary prevention as it remains probable that there } \\
\text { is a role for B - vitamins in the primary prevention of } \\
\text { stroke. }\end{array}$ & RCT \\
\hline
\end{tabular}

"Hyperhomocysteinemia", "elevated homocysteine and cardiovascular disease", which revealed 379 entries related to the period January 1994 to May 2013. From these entries just twenty four (282,727 participants) met the initial set criteria.

This was followed by a methodological quality assessment conducted by two authors employing AMSTAR, which is a one-page tool comprising eleven questions that checks the quality of the studies and the level of agreement obtained by the reviewers. Each question was scored as one point for a 'Yes' answer and a score of zero for all other answers. The outcome was statistically analysed employing Kappa (k) statistics. A calculation was made to establish the mean $\mathrm{k}$ at $95 \%(\mathrm{Cl})$ employing Student's $\mathrm{t}$ test. The non-systematic reviews/meta-analyses were assessed by one author and checked by another for methodological validity employing standardised data extraction tools from JB1000308 [51].

\section{RESULTS}

The search revealed eleven meta-analyses, one systematic review, two systematic review and metaanalyses, and ten other studies, see Table 1.

The fourteen initially screened systematic reviews/meta-analyses studies mean $\mathrm{k}, 95 \%(\mathrm{Cl})$ was 0.77, which scored a Kappa interpretation of 'Substantial Agreement', between the reviewers, presented in Table 2. The remaining studies, met the requirements of the extraction tools from JB1000308 [51].

Twenty four CVD conditions (82.8\%) of the twenty four studies examined, demonstrate that epidemiologic and clinical data indicate that elevated plasma tHcy is a risk factor for CVD [22-25, 29, 42-44, 46, 48, 52-58].

Twenty CVD conditions (71.4\%) of the twenty four studies found that plasma tHcy levels can be employed 
Table 2: Kappa (k) Statistic for Agreement for each AMSTAR Question and Proportion of "Yes" Answers, Together with Interpretation of Kappa

\begin{tabular}{|c|c|c|c|}
\hline AMSTAR question? studies) & k (95\% Cl) & $\begin{array}{l}\text { Reviews scoring an agreed } \\
\text { "yes" (out of } 15(\%)\end{array}$ & Interpretation of kappa $[69,70]$ \\
\hline 1. A priori design? & $1.0(1.0,1.0)$ & 40 & Almost perfect agreement \\
\hline $\begin{array}{l}\text { 2. Duplicate study selection and data } \\
\text { abstraction? }\end{array}$ & $0.51(0.1,0.92)$ & 33 & Fair agreement \\
\hline 3. Comprehensive literature search? & $0.55(0.1,1.0)$ & 60 & Moderate agreement \\
\hline $\begin{array}{l}\text { 4. Publication status used for } \\
\text { inclusion? }\end{array}$ & $0.59(0.18,1.0)$ & 53 & Moderate agreement \\
\hline $\begin{array}{l}\text { 5. Listed included and excluded } \\
\text { studies? }\end{array}$ & $1.0(1.0,1.0)$ & 10 & Almost perfect agreement \\
\hline $\begin{array}{l}\text { 6. Characteristics of included studies } \\
\text { tabulated? }\end{array}$ & $1.0(1.0,1.0)$ & 93 & Almost perfect agreement \\
\hline $\begin{array}{l}\text { 7. Scientific quality of included studies } \\
\text { assessed? }\end{array}$ & $0.61(0.22,1.0)$ & 33 & Substantial agreement \\
\hline $\begin{array}{l}\text { 8. Scientific quality appropriately to } \\
\text { formulated conclusions? }\end{array}$ & $0.61(0.22,1.0)$ & 33 & Substantial agreement \\
\hline $\begin{array}{l}\text { 9. Appropriate methods used to } \\
\text { combine studies? }\end{array}$ & $1.0(1.0,1.0)$ & 80 & Almost perfect agreement \\
\hline $\begin{array}{l}\text { 10. Likelihood of publication bias } \\
\text { assessed? }\end{array}$ & $0.55(0.1,1.0)$ & 20 & Moderate agreement \\
\hline 11. Conflict of interest included? & $1.0(1.0,1.0)$ & 50 & Almost perfect agreement \\
\hline Mean $(\mathrm{k}) 95 \%(\mathrm{Cl})$ & $0.77(0.62,0.92)$ & & Substantial agreement \\
\hline
\end{tabular}

Table 2 outlines the results of the agreement reached by the reviewers of the fourteen systematic reviews/meta-analyses studies that met the initial set criteria, with each study being addressed by the eleven AMSTAR questions.

as a biomarker for the risk of CVD $[22,24,25,29,42$, $43,46,48,52-59]$.

Ueland et al. [25]; Ubbink [27]; Stanger et al. [28]; Robinson et al. [29] and Boushey et al. [43] demonstrated that the odds ratio for the risk of developing CHD increases with increasing plasma tHcy. The results are presented in Figure 2.

Twelve CVD conditions (46.2\%) of the twenty four studies indicated that reducing elevated plasma tHcy reduces the risk of CVD [24, 42, 43, 53 54, 56, 58, 60, 61 ], whilst $23.1 \%$ of the studies did not support this [22, $44,53,62,67]$. The remaining studies reached no conclusion or did not comment [23, 25, 29, 46, 48, 52, $59,68]$.

\section{DISCUSSION}

\section{Cardiovascular Disease}

Bazzano et al. [65] found that there was no evidence to support that reducing homocysteine reduced the risk of CVD. However, a subsequent study conducted by Bleie [66] demonstrated that two years of homocysteine-lowering treatment with moderate doses of folic acid and vitamin B12 improved coronary blood flow, reflecting improved coronary vascular function. Ray [46] demonstrated a significant risk for venous thromboembolic disease in the presence of $\mathrm{HHCY}$, with the risk most significant for patients before the age of 60 years. Boushey et al. [43] demonstrated that a $5 \mu \mathrm{mol} / \mathrm{L}$ increase in plasma tHcy is associated with an increased risk of CVD by an odds ratio of 1.6 in men and 1.8 for women; furthermore, it increased the risk associated with cerebrovascular disease by an odds ratio of 1.5 in both gender. Elevated plasma tHcy was also shown to be an independent graded risk factor for arteriosclerotic vascular disease. McNulty et al. [61] concluded that emerging nutrition policy should consider nutrient requirements aimed at prevention of primary CVD events, as it remained probable that there is a role for B-vitamins in the prevention of primary stroke. Veeranna et al. [55] demonstrated that the results of their study lend support to previously published data exploring the association between Hcy and CVD and CHD events. In contrast to other studies Clarke et al. [67] found that from unpublished studies that lifelong moderate homocysteine elevation had little or no effect on CHD of MTHFR case control studies. It is assumed here that moderate homocysteine elevation 


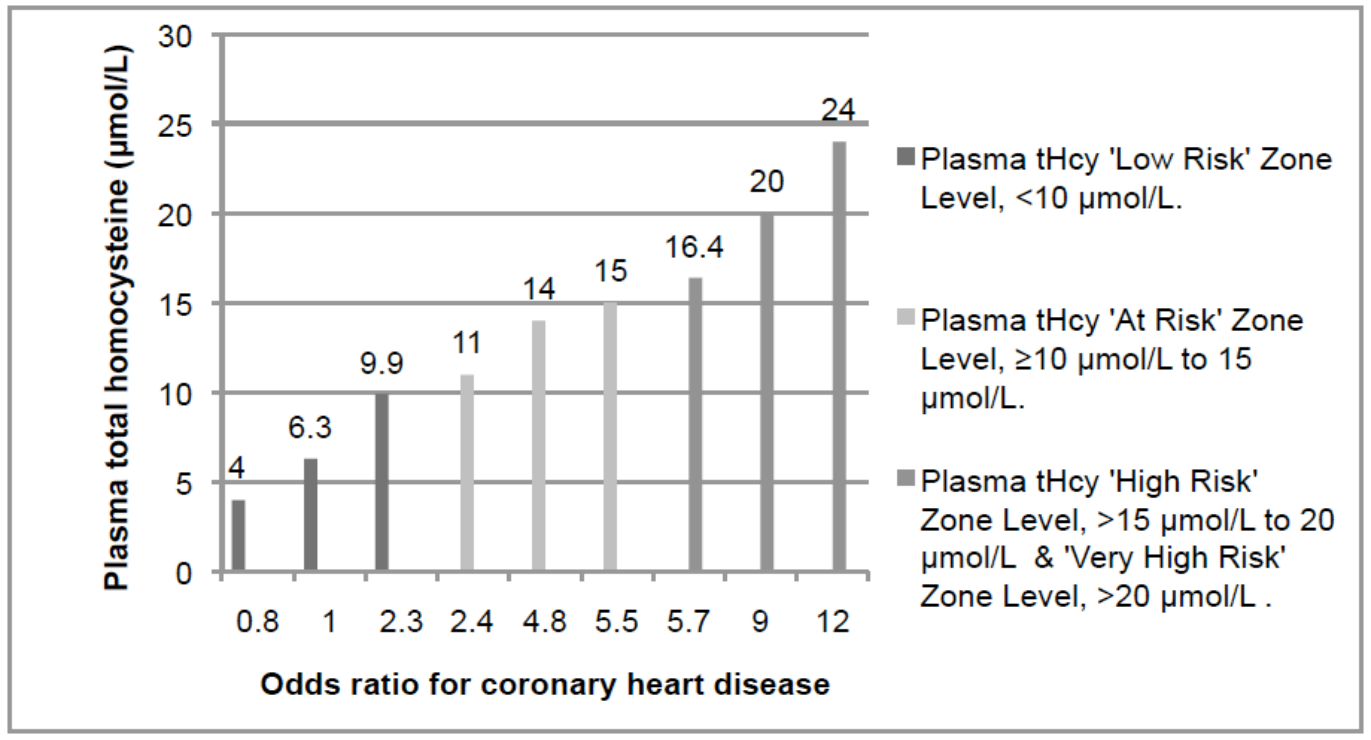

Figure 2: The odds ratio for coronary heart disease compared to plasma total homocysteine.

is equivalent to 15 to $30 \mu \mathrm{mol} / \mathrm{L}[3,20]$. However, no reference was made to homocysteine elevation being higher than this. In addition, Clarke and colleagues findings reveal a claimed serious example of publication bias and argue against the use of folate supplements as a means of reducing CHD risk.

\section{Factors Contributing to Increased Plasma tHcy}

Unhealthy lifestyle, a low intake of B-vitamins, gastrointestinal malabsorption of vitamins, and drug interactions are the most frequent causes that lead to HHCY. Notably, age and gender have a bearing on homocysteine levels. Obersby et al. [9] demonstrated that vegetarians usually have elevated plasma tHcy levels and are therefore susceptible to developing elevated homocysteine related CVD. As an consequence, diet can significantly affect levels also. Smoking is strongly associated with increased homocysteine levels [64]. High consumption of coffee, inadequate nutrition, lack of physical exercise, and stress together with alcohol are all associated with elevated homocysteine levels.

Severe hyperhomocysteinemia can be caused by impaired renal function and a rare autosomal recessive genetic disorder due to a deficiency in the enzyme CBS causing homocysteine to rise sharply. It can also be caused more commonly by mutations of the enzyme MTHFR allowing homocysteine to rise. The findings show that diet, supplementation and lifestyle can have a profound effect on levels of plasma tHcy. A diet rich in homocysteine-lowering nutrients containing vegetables, fruits, legumes, lean meat, fish, whole grains and cereals together with maintaining a healthy lifestyle is a good foundation for healthy levels of homocysteine. It is unlikely that modifications to an unhealthy diet and lifestyle alone would normalise levels of intermediate and severe HHCY classifications without the use of supplements. The findings of the present study show that there is an inverse relationship between folic acid, vitamin B12 and plasma tHcy. It is widely accepted that, at a cellular level, homocysteine exerts a detrimental effect on arterial walls. In addition its reactive product, HCYT, encourages clot formation and generates superoxide and hydrogen peroxide which enhances thrombogenicity. Epidemiological studies have clearly indicated that plasma tHcy is an independent risk factor for atherosclerosis. Raised homocysteine depletes magnesium that can elevate blood pressure through vasoconstriction. There is considerable epidemiologic evidence and clinical data available to support the hypothesis that levels of plasma tHcy can be employed as a major independent risk factor for CVD.

Taken together, the data indicates that elevated plasma tHcy is contributory to many aspects of CVD, and can be employed as an independent biomarker. Furthermore, the difficult to prove hypothesis that reducing plasma tHcy lowers the risk of some CVD events remains unclear, although $46.2 \%$ of the CVD conditions in the studies found that reducing plasma tHcy reduces the risk of a considerable amount of CVD events, and it is therefore prudent to take steps to aim for normal levels of plasma tHcy, as a precaution to avoid the risk of developing or exacerbating CVD. 


\section{ACKNOWLEDGEMENT}

This research received no specific grant from any funding agency in the public, commercial or not forprofit sectors. There are no conflicts of interest. The contribution made by DO was that of lead researcher and was responsible for the compilation of the manuscript. DCC and AAT were responsible for checking the methodological validity of the initially selected studies employing AMSTAR and standardised data extraction tools from JBI Library of Systematic Reviews with any disagreement being resolved through discussion with a third reviewer; together with checking the accuracy of the finalised manuscript.

\section{ACRONYMS}

$\begin{array}{ll}\text { AMSTAR } & \begin{array}{l}\text { Assessment of Multiple Systematic } \\ \text { Reviews }\end{array} \\ \text { CBS } & =\text { Cystathionine } \beta \text {-synthase } \\ \text { CHD } & =\text { Coronary heart disease } \\ \text { CVD } & =\text { Cardiovascular disease } \\ \text { FDA } & =\text { Food and drug administration } \\ \text { HCYT } & =\text { Homocysteine thiolactone } \\ \text { HHCY } & =\text { Hyperhomocysteinemia } \\ \text { JBI } & =\text { Joanna Briggs Institute } \\ \text { LDL } & =\text { Low-density lipoproteins }\end{array}$

LV-LOV'S $=$ Lactovegetarians or lactoovovegetarians

MTHFR = Methylenetetrahydrofolate reductase

PAD $=$ Peripheral arterial disease

SAM = S-adenosylmethionine

tHcy $=$ Total homocysteine

\section{REFERENCES}

[1] Herrmann W, Obeid R, Schorr $\mathrm{H}$, et al. The usefulness of holotranscobalamin in predicting vitamin B12 status in different clinical settings. Cur Drug Meta 2005; 6: 47-53. http://dx.doi.org/10.2174/1389200052997384

[2] Ravaglia G, Forti P, Maioli F, et al. Apolipoprotein E e4 allele affects risk of hyperhomocysteinemia in the elderly. Am J Clin Nutr 2006; 84: 473-1480.

[3] Refsum $\mathrm{H}$, Smith $\mathrm{AD}$, Ueland $\mathrm{PM}$, et al. Facts and recommendations about total homocysteine determinations: 'An Expert Opinion'. Clin Chem 2004; 50: 3-32.

http://dx.doi.org/10.1373/clinchem.2003.021634
Mudd SH, Finkelstein JD, Refsum D, et al. Homocysteine and its disulfide derivatives: a suggested consensus terminology. Arts, Throm Vas Bio 2000; 20: 1704-1706. http://dx.doi.org/10.1161/01.ATV.20.7.1704

[5] Wilcken DE, Wilcken B. The natural history of vascular disease in homocystinuria and the effects of treatment. $J$ Inhere Metab Dis 1997; 20: 295-300. http://dx.doi.org/10.1023/A:1005373209964

[6] McNulty $\mathrm{H}$, McKinley MC, Wilson B, et al. Impaired functioning of thermolabile methylenetetrahydrofolate reductase is dependent on riboflavin status: implications for riboflavin requirements. Am J Clin Nutr 2002; 76: 436-41.

[7] Jacques PF, Rosenberg IH, Rogers G, et al. Serum total homocysteine concentrations in adolescent and adult Americans: results from the Third National Health and Nutrition Examination Survey. Am J Clin Nutr 1999; 69: 482489.

[8] Tallova J, Tomandl J, Bicikova M, et al. Changes of plasma total homocysteine levels during the menstrual cycle. Eur $\mathrm{J}$ Clin Invest 1999; 29: 1041-1044. http://dx.doi.org/10.1046/j.1365-2362.1999.00572.x

[9] Obersby D, Chappell DC, Dunnett A, et al. Plasma tota homocysteine status of vegetarians compared with omnivores: a systematic review and meta-analysis. Brit $J$ Nutr 2013; 109: 785-794. http://dx.doi.org/10.1017/S000711451200520X

[10] Tice JA, Ross E, Coxson PG Cost-effectiveness of vitamin therapy to lower plasma homocysteine levels for prevention of coronary heart disease: effect of grain fortification and beyond. J Am Med Ass 2001; 286: 936-943. http://dx.doi.org/10.1001/jama.286.8.936

[11] Selhub J, Jacques P, Rosenberg IH, Rogers G, et al. Serum total homocysteine concentrations in the Third National Health and Nutrition Examination Survey (1991-1994): population reference ranges and contribution of vitamin status to high serum concentrations. Ann Inter Med 1999; 131: 331-339.

http://dx.doi.org/10.7326/0003-4819-131-5-199909070$\underline{00003}$

[12] Yang Q, Botto LD, Erickson JD, et al. Improvement in stroke mortality in Canada and the United States 1990 to 2002 Circulation 2006; 113: 1335-1343.

http://dx.doi.org/10.1161/CIRCULATIONAHA.105.570846

[13] Morita $\mathrm{H}$. Homocysteine is particularly harmful to arteries in the presence of high salt intake. Diet-induced mild hyperhomocysteinemia and increased salt intake diminish vascular endothelial function in a synergistic manner. $J$ Hyper 2002; 20: 55-62.

http://dx.doi.org/10.1097/00004872-200201000-00009

[14] Fleming RM. The effect of high, moderate and low-fat diets on weight loss and cardiovascular disease risk factors. Prev Cardio 2002; 5: 110-118. http://dx.doi.org/10.1111/j.1520-037X.2002.01231.x

[15] Millian NS, Garrow TA. Human betaine-homocysteine methyltransferase is a zinc metalloenzyme. Arc Biochem and Biophys 1998; 356: 93-98.

http://dx.doi.org/10.1006/abbi.1998.0757

[16] Olthof MR. Consumption of high doses of chlorogenic acid present in coffee or black tea increases plasma total homocysteine concentrations in humans. J Clin Nutr 2001; 73(3): 532-538.

[17] Bleich K, Bleich K, Kropp S, et al. Moderate alcohol consumption in social drinkers raises plasma homocysteine levels: a contradiction to the 'French Paradox'? Alco, Alcoholism 2001; 36 (3): 189-192.

http://dx.doi.org/10.1093/alcalc/36.3.189

[18] de Oliveira AC, Suchecki D, Cohen S, et al. Acute stresserselactive effect on plasma total homocysteine concentration in rats. Pharm Biochem Behaviour 2004; 77: 268-273. 
[19] Stein JH. Smoking cessation, but not smoking reduction, reduces plasma homocysteine levels. Clin Cardio 2002; 25: 23-26.

http://dx.doi.org/10.1002/clc.4950250107

[20] Refsum H, Ueland PM, Nygard O, et al. Homocysteine and cardiovascular disease. Ann Rev Med 1998; 49: 31-62. http://dx.doi.org/10.1146/annurev.med.49.1.31

[21] Welch GN, Loscalzo J. Homocysteine and atherothrombosis. N Eng J Med 1998; 338: 1042-1050. http://dx.doi.org/10.1056/NEJM199804093381507

[22] Khandanpour N, Loke YK, Meyer PJ, Armon MP. Homocysteine and peripheral arterial disease: a systematic review and meta-analysis. Eur J Vascular Endovas Surg 2009; 38: 316-322.

http://dx.doi.org/10.1016/j.ejvs.2009.05.007

[23] Ford ES, Smith SJ, Stroup D, et al. Homocysteine and cardiovascular disease: a systematic review of the evidence with special emphasis on case-control studies and nested case-control studies. Inter J Epidem 2002; 31: 59-70. http://dx.doi.org/10.1093/ije/31.1.59

[24] Humphrey LL, Fu R, Rogers K, et al. Homocysteine level and coronary heart disease: a systematic review and metaanalysis. Mayo Clinic Proc 2008; 83: 1203-1212. http://dx.doi.org/10.4065/83.11.1203

[25] Ueland PM, Refsum H, Beresford M, et al. The controversy over homocysteine and cardiovascular risk. Am J Clin Nutr 2000; 72: 324-332.

[26] Malinow MR, Boston AG, Krauss RM. Homocysteine, diet and cardiovascular disease. Circulation 1999; 99: 178-182. http://dx.doi.org/10.1161/01.CIR.99.1.178

[27] Ubbink JB. What is a desirable homocysteine level? Carmel $\mathrm{R}$ Jacobsen, $\mathrm{D}$. W eds. Homocysteine in health and disease. Cambridge, Cambridge University Press 2001.

[28] Stanger O, Herrmann W, Pietrzik K, et al. Homocysteine [German, Austrian and Swiss Homocysteine Society]: Consensus paper on the rational clinical use of homocysteine, folic acid and B vitamins in cardiovascular and thrombotic disease: Guidelines and recommendations. Clin Chem Lab Me 2003; 41: 1392-1403. http://dx.doi.org/10.1515/CCLM.2003.214

[29] Robinson K, Miller DP, van Lente $F$, et al. Hyperhomocysteinemia and low pyridoxal phosphate. Common and independent reversible risk factors for coronary artery disease. Circulation 1995; 92: 2825-2830. http://dx.doi.org/10.1161/01.CIR.92.10.2825

[30] Guttormsen AB, Ueland PM, Suarstad E, et al. Kinetic basis of hyperhomocysteinemia in patients with chronic renal failure. Kidney Intl 1997; 52: 59-62.

http://dx.doi.org/10.1038/ki.1997.359

[31] Arnadottir M, Hultberg B, Nilsson-Ehle $P$, et al. The effect of reduced glomerular filtration rate on plasma total homocysteine concentration. Scand J Clin Invest 1996; 56: 41-46.

http://dx.doi.org/10.3109/00365519609088586

[32] McCully KS. Chemical pathology of homocysteine 'I. Atherogenesis'. Ann Clin Lab Science 1993; 23: 477-493.

[33] Naruszewicz M, Mirkiewicz E, Olszewski AJ, et al. Thiolation of low density lipoprotein by homocysteine thiolactone causes increased aggregation and interaction with cultured macrophages. Nutr Metab Cardio Dis 1994; 4: 70-77.

[34] Wald NJ, Watt HC, Law MR. Homocysteine and ischaemic heart disease. Arch Inter Med 1998; 158: 862-867. http://dx.doi.org/10.1001/archinte.158.8.862

[35] George NW, Joseph L. Homocysteine and atherothrombosis. N Eng J Med 1998; 338: 1042-1049. http://dx.doi.org/10.1056/NEJM199804093381507

[36] McCully KS. The biomedical significance of homocysteine. J Scientific Explore 2001; 15: 5-20.
[37] Fruchart JC, Nierman MC, Stroes ESG, et al. New risk factors for atherosclerosis and patient risk assessment. Circulation 2004; 109: 1115-1119. http://dx.doi.org/10.1161/01.CIR.0000131513.33892.5b

[38] Harker LA, Slichter SJ, Scott C, et al. Homocysteinemia: vascular injury and arterial thrombosis. N Eng J Med 1984; 291: 537-543.

http://dx.doi.org/10.1056/NEJM197409122911101

[39] Altura BM. Sudden-death ischemic heart disease and dietary magnesium intake: Is the target site coronary vascular smooth muscle? Med Hypotheses 1979; 8: 843-848. http://dx.doi.org/10.1016/0306-9877(79)90074-4

[40] Altura BT, Altura BM. Magnesium in cardiovascular biology. Scientific American May/June 1995; 28-36.

[41] Li W, Zheng T, Wang J, et al. Homocysteine results in magnesium depletion from vascular smooth muscle. $J$ Neuroscience 1999; 274: 83-86.

[42] Wald DS, Law M, Morris JK. Homocysteine and cardiovascular disease: evidence on causality from a metaanalysis. Brit Med J 2002; 325: 1202.

http://dx.doi.org/10.1136/bmj.325.7374.1202

[43] Boushey CJ, Beresford SA, Omenn GS, et al. A quantitative assessment of plasma homocysteine as a risk factor for vascular disease: probable benefits of increasing folic acid intakes. J Am Med Ass 1995; 274: 1049-1057. http://dx.doi.org/10.1001/jama.1995.03530130055028

[44] Eikelboom JM, Lonn E, Genest J, et al. Homocyst(e)ine and cardiovascular disease: a critical review of the epidemiologic evidence. Ann Inter Med 1999; 131: 363-375. http://dx.doi.org/10.7326/0003-4819-131-5-19990907000008

[45] Brattstrom L, Wilcken DEL. Homocysteine and cardiovascular disease: cause or effect? Am J Clin Nutr 2000; 72: 315-323.

[46] Ray JG. Meta-analysis of hyperhomocysteinemia as a risk factor for venous thromboembolic disease. Arch Inter Med 1998; 158: 2101-6.

http://dx.doi.org/10.1001/archinte.158.19.2101

[47] Eichinger S, Stumpflen A, Hirschl M. Hyperhomocysteinemia is a risk factor of recurrent venous thromboembolism. J Throm Haemos 1998; 80: 566-9.

[48] Langman LJ, Ray JG, Evrovski J, et al. Hyperhomocysteinemia and the increased risk of venous thromboembolism. Arch Inter Med 2000; 160: 961-964. http://dx.doi.org/10.1001/archinte.160.7.961

[49] Fry FH, Wilson BD, Gubler DB, et al. Homocysteine, a risk factor for premature vascular disease and thrombosis, induces tissue factor activity in endothelial cells. Arterios Throm Vasc Bio 1993; 13: 1327-1333.

http://dx.doi.org/10.1161/01.ATV.13.9.1327

[50] Fermo I, Vigano D' Angelo S, Paroni R, et al. Prevalence of moderate hyperhomocysteinemia in patients with early-onset venous and arterial occlusive disease. Ann Inter Med 1995; 123: $747-753$.

http://dx.doi.org/10.7326/0003-4819-123-10-199511150$\underline{00002}$

[51] JB1000308. Qualitative, meta-analysis of statistics assessments and review instruments. Joanna Briggs Inst 2011; 9: 104-121.

[52] Bautista LE, Arenas IA, Penuela A, et al. Total plasma homocysteine level and risk of cardiovascular disease: $A$ meta-analysis of prospective cohort studies. J Clin Epidem 2002; 55: 882-887.

http://dx.doi.org/10.1016/S0895-4356(02)00434-1

[53] Tanne D, Haim M, Goldbourt U, et al. Prospective study of serum homocysteine and risk of ischemic stroke among patients with pre-existing coronary heart disease. Stroke 2003; 34: 632-636

http://dx.doi.org/10.1161/01.STR.0000060203.58958.35 
[54] The Homocysteine Studies Collaboration. Homocysteine and risk of ischemic heart disease and stroke: a meta-analysis. J Am Med Ass 2002; 288: 2015-2022. http://dx.doi.org/10.1001/jama.288.16.2015

[55] Veeranna V, Zalawadiya SK, Niraj A, et al. Homocysteine and reclassification of cardiovascular disease risk. J Am Col Card Found 2011; 58: 1025-33. http://dx.doi.org/10.1016/j.jacc.2011.05.028

[56] Pancharuniti N, Lewis CA, Sauberlich HE, et al. Plasma homocysteine, folate, and vitamin B12 concentrations and risk of early onset coronary artery disease. Am J Clin Nut 1994; 59: 940-8.

[57] Govindaraju V, Manjunath CN, Risk prediction-homocysteine in coronary heart disease. Ind J Clin Bio 2007; 22(1): 18-21. http://dx.doi.org/10.1007/BF02912875

[58] Wang X, Qin X, Demirtas $\mathrm{H}$, et al. Efficacy of folic acid supplementation in stroke prevention: a meta-analysis. Lancet 2007; 369: 1876-1882. http://dx.doi.org/10.1016/S0140-6736(07)60854-X

[59] Verhoef $\mathrm{P}$, Stampfer MJ, Buring JE, et al. Homocysteine metabolism and risk of myocardial infarction: relation with vitamins B6, B12, and folate. Am J Epidemiol 1996; 143(8): 845-59.

http://dx.doi.org/10.1093/oxfordjournals.aje.a008828

[60] de Bree A, van Mierlo LA, Draijer R. Folic acid improves vascular reactivity in humans: a meta-analysis of randomised controlled trials. Am J Clin Nutr 2007; 86: 610-617.

[61] McNulty H, Strain JJ, Pentieva K, et al. C1 metabolism and CVD outcomes in older adults. Proc Nutr Soc 2012; 71: 213221. http://dx.doi.org/10.1017/S0029665111003387

[62] The Heart Outcomes Prevention Evaluation (HOPE2) Investigators. Homocysteine Lowering with Folic Acid and B
Vitamins in Vascular Disease. N Eng J Med 2006; 354: 15671577.

http://dx.doi.org/10.1056/NEJMoa060900

[63] Clarke R, Halsey J, Lewington S, et al. Effects of lowering homocysteine levels with B vitamins on cardiovascular disease, cancer, and cause-specific mortality .Arch Inter Med 2010; 179: 1622-1631.

[64] Nygard O, Refsum H, Ueland PM, et al. Major lifestyle determinants of plasma total homocysteine distribution: 'The Hordaland Homocysteine Study'. Am J Clin Nutr 1998; 67: 263-270

[65] Bazzano LA, Reynolds K, Holder KN, et al. Effect of folic acid supplementation on risk of cardiovascular disease. J Am Med Assoc 2006; 296: 2720-2726. http://dx.doi.org/10.1001/jama.296.22.2720

[66] Bleie O. Studies on Homocysteine-lowering B-vitamin Therapy in patients with coronary artery disease. Dr.med dissertation, University of Bergen, Norway 2008.

[67] Clarke R, Bennett A, Parish S, et al. Homocysteine and coronary heart disease: meta-analysis of MTHFR casecontrol studies, avoiding publication bias. Plos Med 2012. http://dx.doi.org/10.1371/journal.pmed.1001177

[68] Gravina-Taddei CF, Batlouni N, Sartesch C, et al. Hyperhomocysteinemia as a risk factor for coronary atherosclerotic diseases in the elderly. Arq Bras Cardiol 2005; 85(3): 1-11.

[69] Viera AJ, Garrett JM. Understanding inter-observer agreement: the Kappa statistic. Family Med 2005; 37: 360-3.

[70] Shea BJ, Hamel C, Wells GA, et al. AMSTAR is a reliable and valid measurement tool to assess the methodological quality of systematic reviews. J Epidem 2009; 62: 10131020.

http://dx.doi.org/10.1016/j.jclinepi.2008.10.009 